\title{
Trans-equatorial migration and habitat use by sooty shearwaters Puffinus griseus from the South Atlantic during the nonbreeding season
}

\author{
April Hedd ${ }^{1, *}$, William A. Montevecchi ${ }^{1}$, Helen Otley ${ }^{2}$, Richard A. Phillips ${ }^{3}$, \\ David A. Fifield ${ }^{1}$ \\ ${ }^{1}$ Cognitive and Behavioural Ecology Program, Psychology Dept., Memorial University, St. John's, Newfoundland A1C 3C9, \\ Canada \\ ${ }^{2}$ Environmental Planning Dept., Falkland Islands Government, Stanley, Falkland Islands FFI 1ZZ, UK \\ ${ }^{3}$ British Antarctic Survey, Natural Environment Research Council, High Cross, Madingley Road, Cambridge CB3 0ET, UK
}

\begin{abstract}
The distributions of many marine birds, particularly those that are highly pelagic, remain poorly known outside the breeding period. Here we use geolocator-immersion loggers to study trans-equatorial migration, activity patterns and habitat use of sooty shearwaters Puffinus griseus from Kidney Island, Falkland Islands, during the 2008 and 2009 nonbreeding seasons. Between mid March and mid April, adults commenced a $\sim 3 \mathrm{wk},>15000 \mathrm{~km}$ northward migration. Most birds (72\%) staged in the northwest Atlantic from late April to early June in deep, warm and relatively productive waters west of the Mid-Atlantic Ridge $\left(\sim 43-55^{\circ} \mathrm{N}, \sim 32-43^{\circ} \mathrm{W}\right)$ in what we speculate is an important moulting area. Primary feathers grown during the moult had average $\delta^{15} \mathrm{~N}$ and $\delta^{13} \mathrm{C}$ values of $13.4 \pm 1.8 \%$ and $-18.9 \pm 0.5 \%$, respectively. Shearwaters moved into shallow, warm continental shelf waters of the eastern Canadian Grand Bank in mid June and resided there for the northern summer. Migrant Puffinus shearwaters from the southern hemisphere are the primary avian consumers of fish within this ecosystem in summer. During migration birds flew for $78 \%$ of the day and $59 \%$ of the night, whereas when resident in the northern hemisphere they spent much of their time on the water $(70 \%$ daylight, $90 \%$ darkness). Shearwaters moved south late August to mid September, completing the $\sim 30000 \mathrm{~km}$ figure-of-eight round trip migration in $\sim 2$ to $3 \mathrm{wk}$. The Northern Patagonian Shelf and Argentine Basin were used as a terminal stopover site, where most $(79 \%)$ shearwaters spent $\sim 1 \mathrm{wk}$ before first returning to the breeding colony for the season. Year-round tracking of seabirds aids the identification of important marine areas and highlights regions where conservation efforts need to be focused.
\end{abstract}

KEY WORDS: Trans-equatorial migration - Habitat preference · GLS loggers · Nonbreeding distribution · Activity patterns $\cdot$ Puffinus griseus $\cdot$ Atlantic Ocean

\section{INTRODUCTION}

Our window into, and consequently our understanding of, the spectacle of marine animal migration is ever widening as tracking technologies advance and remotely sensed environmental data are being incorporated in increasingly sophisticated ways
(Shaffer et al. 2006, Felicísimo et al. 2008, GonzálezSolís et al. 2009, Wakefield et al. 2009). Miniaturized global location sensing (GLS or geolocator) devices in particular have been instrumental in providing information about spatio-temporal changes in the distribution of smaller species, providing details of some of the most spectacular migrations on record 
(Croxall et al. 2005, Phillips et al. 2005, GonzálezSolís et al. 2007, Guilford et al. 2009, Egevang et al. 2010). The annual trans-equatorial migrations of shearwaters, for example, inferred originally from banding studies and shipboard surveys (e.g. Brooke 1990, Spear \& Ainley 1999), have been confirmed through tracking in both the Pacific and Atlantic Oceans (Shaffer et al. 2006, González-Solís et al. 2007, Guilford et al. 2009). Understanding the distributional patterns of wide-ranging marine animals, and the physical and biological processes that influence them at ocean basin scales, will help ongoing efforts to identify ecologically and biologically significant areas as targets for pelagic biodiversity conservation (Game et al. 2009, Block et al. 2011).

The trans-equatorial migrations of many shearwaters are driven by highly seasonal food availability, enabling birds to exploit rich summer food supplies for much of the year, at both ends of their distributional range (Shaffer et al. 2006, GonzálezSolís et al. 2007, Guilford et al. 2009). The rapid migrations are at least partially assisted by global wind patterns (Felicísimo et al. 2008, González-Solís et al. 2009) which run clockwise in the northern and counter-clockwise in the southern hemisphere and result in the figure-of-eight movement strategies reported for sooty shearwaters Puffinus griseus in the Pacific and some Cory's shearwaters Calonectris diomedea in the Atlantic (Shaffer et al. 2006, González-Solís et al. 2007).

Sooty shearwaters breed in the southern hemisphere, with substantial populations in New Zealand, southeast Australia, southern Chile and the Falkland Islands. Although the total number of sooty shearwaters may exceed 20 million individuals (Brooke 2004), there are signs of population decline both at breeding colonies in New Zealand (Lyver et al. 1999, Scott et al. 2008) and on the North Pacific wintering grounds, coincident with increased ocean temperatures, reduced biological productivity and high levels of bycatch in driftnet fisheries (Veit et al. 1996, 1997, Uhlmann et al. 2005). Post-breeding birds from New Zealand cover $>60000 \mathrm{~km}$ on roundtrip migrations and spend the nonbreeding period in discrete areas off Japan, Alaska or California (Shaffer et al. 2006). Sooty shearwaters therefore integrate resources annually over whole ocean scales, and this has led to the suggestion that their populations may serve as important indicators of both climate change and ocean 'health' (Shaffer et al. 2006). In the northwest Atlantic, migrant great Puffinus gravis and sooty shearwaters from the southern hemisphere are the major avian consumers of fish during the northern summer (Barrett et al. 2006); however, there is very little information on the provenance or the age classes of the latter. Spring and summer shipboard observations of sooty shearwaters in fresh plumage off eastern Canada (Scotian Shelf, Newfoundland Grand Bank and Labrador Sea), led Brown (1988) to conclude that the portion of the population migrating to the North Atlantic likely consisted of immature birds.

In this study we used geolocator-immersion loggers combined with stable isotope analysis of feathers to clarify movements and to examine trophic level of sooty shearwaters from the South Atlantic Ocean during the nonbreeding season. Specifically, our objectives were to identify the timing and routes of migration, the duration of residence at the main staging and wintering areas, and to examine habitat associations and trophic level. We report on the full nonbreeding period; from outward migration at the end of one breeding season to the subsequent return to the colony.

\section{MATERIALS AND METHODS}

\section{Logger deployment}

The fieldwork was conducted during austral summers 2007/08, 2008/09 and 2009/10 at Kidney Island, Falkland Islands $\left(51^{\circ} 37^{\prime} \mathrm{S}, 57^{\circ} 45^{\prime} \mathrm{W}\right.$; Fig. 1), a site where $>100000$ pairs of sooty shearwaters breed (Woods et al. 2006). Between 10 and 13 December 2007, we deployed geolocator-immersion or geolocator-immersion-temperature loggers attached to ovalshaped plastic bands on the tarsi of 44 adult shearwaters, each from a different burrow. Birds were incubating at the time, and individual breeding status was determined either from the presence of an egg at deployment, or subsequently from patterns of colony attendance derived from the light and activity (immersion) data. Device attachment, weighing (using a $1 \mathrm{~kg}$ Pesola spring balance) and banding (Canadian Wildlife Service stainless steel bands) took $\sim 5 \mathrm{~min}$, after which birds were returned to their burrows. Study burrows were marked at the entrance with a metal tag and flagging tape, and left undisturbed for 12 mo. Three types of geolocators or GLSs were deployed in 2007: British Antarctic Survey (BAS) Mk5 (logger + attachment = $5.1 \mathrm{~g} \approx$ $0.6 \%$ body mass, $\mathrm{n}=15$ ) which recorded light, immersion and temperature; BAS Mk13 (logger + attachment $=2.9 \mathrm{~g} \approx 0.3 \%$ body mass, $\mathrm{n}=15$ ) which recorded light and immersion only; and Lotek LAT 


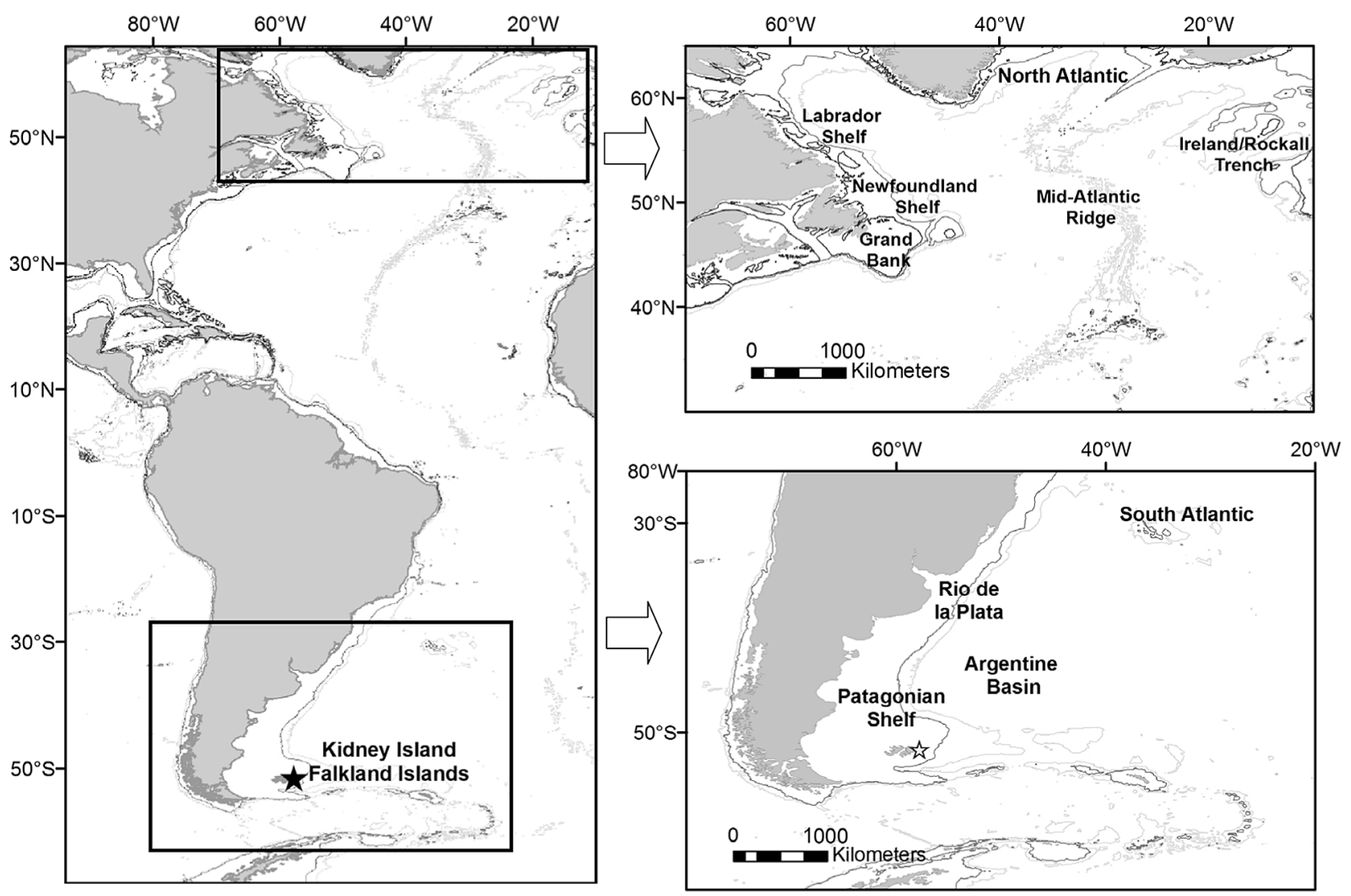

Fig. 1. Location of the study site at Kidney Island, Falkland Islands, and insets of areas used by post-breeding sooty shearwaters in the North and South Atlantic, with locations of marine areas mentioned throughout the text

2500 (logger + attachment $=5.9 \mathrm{~g}, \approx 0.7 \%$ body mass, $\mathrm{n}=14$ ) which recorded light, immersion and temperature (the latter 2 parameters every $240 \mathrm{~s}$ throughout deployment). Geolocators (12 Lotek LAT 2500 [with depth capability], and 2 BAS Mk5) were re-deployed on 14 individuals between 9 and 12 December 2008 to assess the degree of consistency in migratory patterns across years. Burrows were visited during incubation and early chick-rearing in 2008/09 and 2009/10 to retrieve devices. At recapture, birds were weighed, $\sim 2 \mathrm{~cm}$ of a mid-primary feather (5 or 6 ) was sampled for stable isotope analysis, and blood ( $\sim 0.5 \mathrm{ml}$ from brachial vein) was drawn to determine sex using molecular techniques (Fridolfsson \& Ellegren 1999).

\section{Logger processing and analysis}

Light data from the BAS GLS loggers were processed using Transedit software (BAS), using a light threshold of 10, and an angle of elevation of -4.7 (see Phillips et al. 2004). Day/night length is used to provide an estimate of latitude, and Julian date plus the time of local midday/midnight relative to GMT is used to estimate longitude. This procedure produces 2 locations per day, corresponding to local midday and midnight. Light data recorded by Lotek LAT 2500 geolocators is processed internally using template fitting software, producing a single location per day (Ekstrom 2004). Mean positional error \pm SD of similar devices deployed on free-ranging albatrosses was $186 \pm 114 \mathrm{~km}$ (Phillips et al. 2004) and $202 \pm$ $171 \mathrm{~km}$ (Shaffer et al. 2005). Latitude cannot be accurately estimated from light levels during equinox as day length is approximately similar around the globe (Hill 1994), so when possible we obtained latitude estimates during these periods by reconciling temperature data recorded by the loggers (BAS Mk5 and Lotek LAT 2500 only) with satellite sea surface temperature (SST) data (Teo et al. 2004, Shaffer et al. 2005). BAS loggers record temperature (accuracy $\pm 0.5^{\circ}$ above $0^{\circ} \mathrm{C}$, and $\pm 1.0^{\circ}$ from $0^{\circ}$ to $-10^{\circ} \mathrm{C}$ ) only after 20 min of continuous immersion, providing stable surface (or subsurface) temperatures suitable for comparison with satellite derived SST data. Lotek devices recorded temperature (accuracy $\pm 0.2^{\circ} \mathrm{C}$ ) every $4 \mathrm{~min}$, and consecutive readings that varied less than 
the device accuracy over $>24$ min were considered to represent surface temperatures for these comparisons. Light-based latitude data that were clearly affected by proximity to equinox for records without corresponding temperature information (BAS Mk13 and 1 MK5) were excluded. Longitude estimates are unaffected by equinox and were retained to ascertain east-west movements during these times. Clearly erroneous locations derived from light curves with interference around sunrise or sunset were also removed. Validated data were smoothed twice, with raw or fixed positions maintained around periods of missing data (Phillips et al. 2004).

Migration frequently overlapped with periods around equinoxes when light-based latitudes were unavailable, and hence, was fully spatially resolved only for birds with corresponding temperature records. We used the patterns evident in these records to infer migration start and end dates for the remaining individuals. Following the approach of Guilford et al. (2009), birds were considered to have started outward migration on the date they were last recorded within $500 \mathrm{~km}$ of the colony, and to have ended their return migration on the date they first reentered these bounds. Examining light plus activity (immersion) records simultaneously helped distinguish time spent at sea from time in the colony (spells in the burrow were dark and dry), and thus helped resolve the timing of colony departure and return. Most shearwaters (90\%; 18 of 20 records) paused briefly ( 2 to $12 \mathrm{~d}$ ) after leaving the colony, but before starting their northward migration. Where spatially resolved, these pauses generally (91\%; 10 of 11 records) occurred within $500 \mathrm{~km}$ of the colony. In these cases, the start of migration corresponded with a rapid change in longitude coupled with extended dry (i.e. flight) periods, and these indicators were used to estimate the start of migration for records lacking spatial data. On the return (southward) migration, stopovers occurred farther $(>1000 \mathrm{~km})$ from the breeding colony and were thus considered part of the migration itself. Stopovers were determined visually by inspecting the spatial data for obvious interruptions in rapid directional movement that lasted $\geq 2 \mathrm{~d}$. In general, the first location within $500 \mathrm{~km}$ of the colony for each bird coincided with the day they first entered the burrow for the season (based on the light and immersion data), and we assumed this to be the case for records lacking spatial resolution. For individuals with sufficient data, minimum cumulative great circle distances were calculated during migration, assuming straight line travel between periods of missing data.
Locations of the birds at sea were mapped in ArcGIS 9.3 (ESRI, Redlands, CA, USA), and Spatial Analyst and Hawth's Tools, respectively, were used to create kernel density surfaces (North or South Pole Lambert azimuthal equal-area projection; cell size = $50 \mathrm{~km}$, search radius $=200 \mathrm{~km}$ ) and percent volume contours describing the bird's utilization distribution (Phillips et al. 2005). Kernels were produced for late April to early September, when birds were resident on the nonbreeding grounds, and $40 \%$ density contours were considered to correspond to the 'core' or high use areas.

BAS geolocators tested for saltwater immersion every $3 \mathrm{sec}$, and recorded the number of positive tests every $10 \mathrm{~min}$ as a value between 0 (all dry) and 200 (all wet). The immersion data were categorized into day (civil sunrise to civil sunset; sun $6^{\circ}$ below horizon) and night (civil sunset to civil sunrise) and used to determine the proportion of each day and night birds spent flying and sitting on the sea. Any 10 min periods that spanned day to night and night to day were removed from the analyses. Only data from the first to the last complete day of at-sea activity were included in the analyses (Mackley et al. 2011).

\section{Habitat associations}

Marine habitats of nonbreeding sooty shearwaters were characterized by overlaying kernel density contours $(0-20,20-40,40-60,60-80$, and $80-90 \%)$ onto maps of bathymetry and remotely-sensed SST and chlorophyll concentration (chl a). Bathymetry was determined using ETOPO2 grids (www.ngdc.noaa. gov/mgg/global/etopo2.html). SST and chl a were monthly composite Aqua MODIS mapped products at $9 \mathrm{~km}$ resolution, downloaded from http://oceancolor.gsfc.nasa.gov. Habitat associations were restricted to representative periods early (May) and midway through (July) the 2008 nonbreeding period.

\section{Stable isotope analysis}

Feathers were cleaned of surface contaminants using a 2:1 ratio mixture of chloroform:methanol and air dried prior to stable isotope analysis. Isotope ratios of carbon and nitrogen were measured at the Stable Isotope Facility, University of California, Davis using an elemental analyzer interfaced to a continuous flow isotope ratio mass spectrometer, with 2 laboratory standards analyzed for every 12 unknowns. Stable isotope ratios are expressed in delta $(\delta)$ nota- 
Table 1. Puffinus griseus. Migration characteristics of sooty shearwaters tracked using geolocators from Kidney Island, Falkland Islands, in 2008 and 2009. MAR: west or in the immediate vicinity of the Mid-North Atlantic Ridge; E-Can: Eastern Canadian waters off Newfoundland and Labrador; NE-Atl: Northeast Atlantic; U: Sex unknown; -: information unavailable; SST: sea surface temperature

\begin{tabular}{|c|c|c|c|c|c|c|c|c|c|c|c|c|}
\hline \multirow{2}{*}{$\begin{array}{l}\text { Bird } \\
\text { band }\end{array}$} & \multirow{2}{*}{ Sex } & \multirow{2}{*}{ Year } & \multirow{2}{*}{$\begin{array}{l}\text { Colony } \\
\text { departure } \\
\text { date }\end{array}$} & \multicolumn{3}{|c|}{-Northward migration- } & \multicolumn{2}{|c|}{ Nonbreeding region -} & \multicolumn{3}{|c|}{-Southward migration- } & \multirow{2}{*}{$\begin{array}{l}\text { Colony } \\
\text { return } \\
\text { date }\end{array}$} \\
\hline & & & & $\begin{array}{c}\text { Depar- } \\
\text { ture } \\
\text { date }\end{array}$ & $\begin{array}{l}\text { Dura- } \\
\text { tion } \\
\text { (d) }\end{array}$ & $\begin{array}{l}\text { Dis- } \\
\text { tance } \\
(\mathrm{km})\end{array}$ & $\begin{array}{c}\text { Arrival } \\
\text { date } \\
\text { (first area) }\end{array}$ & $\begin{array}{l}\text { Main area(s) } \\
\text { used (Residency } \\
\text { period [d]) }\end{array}$ & $\begin{array}{l}\text { Depar- } \\
\text { ture } \\
\text { date }\end{array}$ & $\begin{array}{l}\text { Dura- } \\
\text { tion } \\
\text { (d) }\end{array}$ & $\begin{array}{l}\text { Dis- } \\
\text { tance } \\
(\mathrm{km})\end{array}$ & \\
\hline $6073^{\mathrm{a}}$ & $\mathrm{F}$ & 2008 & 07-Mar-08 & 14-Mar-08 & 27 & 17116 & 10-Apr-08 & MAR (48), E-Can (114) & 19-Sep-08 & 22 & 16517 & 11-Oct-08 \\
\hline $6092^{\mathrm{b}}$ & M & 2008 & - & 29-Mar-08 & 27 & 18296 & 25-Apr-08 & MAR (40), E-Can (99) & 10-Sep-08 & 20 & - & 30-Sep-08 \\
\hline $6092^{\mathrm{b}}$ & M & 2009 & - & 25-Mar-09 & 27 & 16710 & 21-Apr-09 & MAR (47), E-Can (94) & 8-Sep-09 & 22 & - & 30-Sep-09 \\
\hline $6097^{a}$ & $\mathrm{~F}$ & 2008 & 15-Mar-08 & 18-Mar-08 & 24 & 16468 & 12-Apr-08 & MAR (59), E-Can (89) & 05-Sep-08 & 28 & 15113 & 06-Oct-08 \\
\hline $6075^{\mathrm{a}, \mathrm{c}}$ & ${ }^{c} \mathrm{~F}$ & 2008 & 27-Mar-08 & 27-Mar-08 & 29 & 16733 & 25-Apr-08 & MAR (35), - & - & - & - & - \\
\hline $6075^{\mathrm{a}, \mathrm{c}}$ & ${ }^{c} \mathrm{~F}$ & 2009 & 29-Mar-09 & 31-Mar-09 & 19 & 12885 & 18-Apr-09 & $\operatorname{MAR}(>19),-$ & - & - & - & - \\
\hline $6079^{\mathrm{a}}$ & $\mathrm{M}$ & 2008 & 18-Mar-08 & 24-Mar-08 & 17 & 14982 & 11-Apr-08 & MAR (44), E-Can (107) & 07-Sep-08 & 20 & 14970 & 27-Sep-08 \\
\hline $6079^{\mathrm{a}, \mathrm{c}}$ & ${ }^{\mathrm{c}} \mathrm{M}$ & 2009 & 30-Mar-08 & 4-Apr-09 & - & - & - & - & - & - & - & - \\
\hline $6095^{\mathrm{a}}$ & $\mathrm{F}$ & 2008 & 09-Mar-08 & 09-Mar-08 & 34 & 19308 & 13-Apr-08 & MAR (8), E-Can (138) & 04-Sep-08 & 25 & 13356 & 29-Sep-08 \\
\hline $6076^{\mathrm{a}}$ & $\mathrm{F}$ & 2008 & 27-Mar-08 & 04-Apr-08 & 22 & 14605 & $27-A p r-08$ & MAR (45), E-Can (100) & 18-Sep-08 & 20 & 12740 & 08-Oct-08 \\
\hline $6090^{\mathrm{a}}$ & $\mathrm{F}$ & 2008 & 02-Apr-08 & 05-Apr-08 & 17 & 16568 & 23-Apr-08 & MAR (42), E-Can (100) & 11-Sep-08 & 14 & - & 25-Sep-08 \\
\hline $6077^{\mathrm{a}}$ & $\mathrm{F}$ & 2008 & 24-Mar-08 & 28-Mar-08 & 16 & 13393 & 14-Apr-08 & MAR (56), E-Can (92) & 08-Sep-08 & 24 & 14280 & 02-Oct-08 \\
\hline $6093^{a}$ & M & 2008 & 10-Mar-08 & 22-Mar-08 & 19 & 15001 & 11-Apr-08 & MAR (13), E-Can (137) & 06-Sep-08 & 18 & 13059 & 24-Sep-08 \\
\hline 6085 & $\mathrm{~F}$ & 2008 & 22-Mar-08 & 25-Mar-08 & 19 & 14592 & 14-Apr-08 & E-Can (145) & 06-Sep-08 & 12 & 11955 & 18-Sep-08 \\
\hline 3622 & $\mathrm{~F}$ & 2008 & 01-Apr-08 & 05-Apr-08 & 15 & 13244 & 21-Apr-08 & MAR (32), E-Can (107) & 06-Sep-08 & 25 & - & 01-Oct-08 \\
\hline 3622 & $\mathrm{~F}$ & 2009 & 03-Apr-09 & 03-Apr-09 & 17 & 14940 & 19-Apr-09 & MAR (35), E-Can (111) & 13-Sep-09 & 26 & 14567 & 09-Oct-09 \\
\hline 6100 & M & 2008 & 06-Apr-08 & 10-Apr-08 & 18 & 16699 & 29-Apr-08 & MAR (4), E-Can (117) & 26-Aug-08 & 21 & 14677 & 16-Sep-08 \\
\hline 6091 & $\mathrm{~F}$ & 2008 & 14-Mar-08 & 17-Mar-08 & 24 & - & 11-Apr-08 & MAR (123), NE-Atl (24) & 03-Sep-08 & 24 & 15683 & 27-Sep-08 \\
\hline 3623 & M & 2008 & 25-Mar-08 & 30-Mar-08 & 28 & 17828 & 28-Apr-08 & MAR (38), E-Can (94) & 05-Sep-08 & 18 & - & 23-Sep-08 \\
\hline 6096 & $\mathrm{U}$ & 2008 & 18-Mar-08 & 20-Mar-08 & 18 & - & 08-Apr-08 & MAR (57), E-Can (92) & 06-Sep-08 & 21 & - & 27-Sep-08 \\
\hline 6083 & M & 2008 & 17-Mar-08 & 21-Mar-08 & 18 & - & 09-Apr-08 & MAR (60), E-Can (80) & 26-Aug-08 & 18 & 13852 & 13-Sep-08 \\
\hline 6088 & M & 2008 & 08-Apr-08 & 12-Apr-08 & 15 & 13167 & 28-Apr-08 & E-Can (125) & 29-Aug-08 & 27 & - & 25-Sep-08 \\
\hline Mean & & & $23 \mathrm{Mar}$ & 27 Mar & 21 & 15696 & 17 Apr & & $06 \mathrm{Sep}$ & 21 & 14197 & $28 \mathrm{Sep}$ \\
\hline $\mathrm{SD}$ & & & $9.4 \mathrm{~d}$ & $8.7 \mathrm{~d}$ & 5.4 & 1885 & $7.2 \mathrm{~d}$ & & $6.3 \mathrm{~d}$ & 4.2 & 1287 & $7.2 \mathrm{~d}$ \\
\hline
\end{tabular}

tion in parts per thousand (\%) relative to international standards V-PDB (Vienna PeeDee Belemnite) and air for carbon and nitrogen, respectively. Feathers are metabolically inert after synthesis, and isotope composition of the primaries therefore integrates and reflects that of their diet during the post-nuptial moult, which occurs in the first few months after colony departure (Marchant \& Higgins 1990). Results for stable isotopes and other data are reported as means $\pm 1 \mathrm{SD}$ throughout.

\section{RESULTS}

\section{Retrieval details and breeding status}

Five of our initial 44 study burrows could not be relocated. From the initial deployment, we retrieved loggers from 26 of 39 relocated burrows (67\%; 25 in 2008/09, and 1 in 2009/10); presumed mates of in- strumented birds were found in 8 additional burrows and 5 burrows were empty (trips to recover devices were of limited duration: <1 wk each year). Loggers were also retrieved from 4 of 14 (29\%) birds retagged in 2008. Data were successfully downloaded from 19 of 22 BAS geolocators (3 Mk13 failed, and a single Mk5 yielded a partial record), and 3 partial datasets were obtained from 8 birds that carried Lotek loggers as a result of geolocator loss and device failure. Our dataset includes 19 shearwaters (10 females, 8 males, 1 unknown) tracked for an average of 397 d (range 105 to 726 d); 18 provided data throughout the 2008 nonbreeding period (4 of these birds were also tracked for all or part of the 2009 nonbreeding period; Table 1) and 1 bird was tracked for part of the 2008/09 breeding season only.

An egg in the burrow or a regular incubation attendance rhythm confirmed breeding for 17 of 18 shearwaters for which we obtained tracking data in the 2008 nonbreeding period; 1 individual (Bird 6083; 
Table 1) either lost its egg prior to GLS deployment or did not breed that year. Of breeding birds, 15 of the 17 presumably hatched chicks in January 2008, and regularly attended the colony until March or April 2008 (Table 1), which corresponds to the late chick-rearing period at other sites (Warham et al. 1982). Interrupted incubation rhythms suggested that 2 individuals (Birds 6095 and 6093; Table 1) failed during incubation in 2007/08; however, these birds and Bird 6083 continued to regularly attend the colony into March. The 4 individuals fitted with loggers in 2008/09 were confirmed breeders, and overall $83 \%$ of birds (25 of 30) were breeding when devices were retrieved. The body mass of shearwaters returning with loggers was similar at deployment $(882 \pm 65.6 \mathrm{~g})$ and retrieval either 12 or 24 mo later $\left(881 \pm 62.4 \mathrm{~g}\right.$; paired $t$-test: $t_{22}=$ $0.08, \mathrm{p}=0.938$ ), both measured early in incubation.

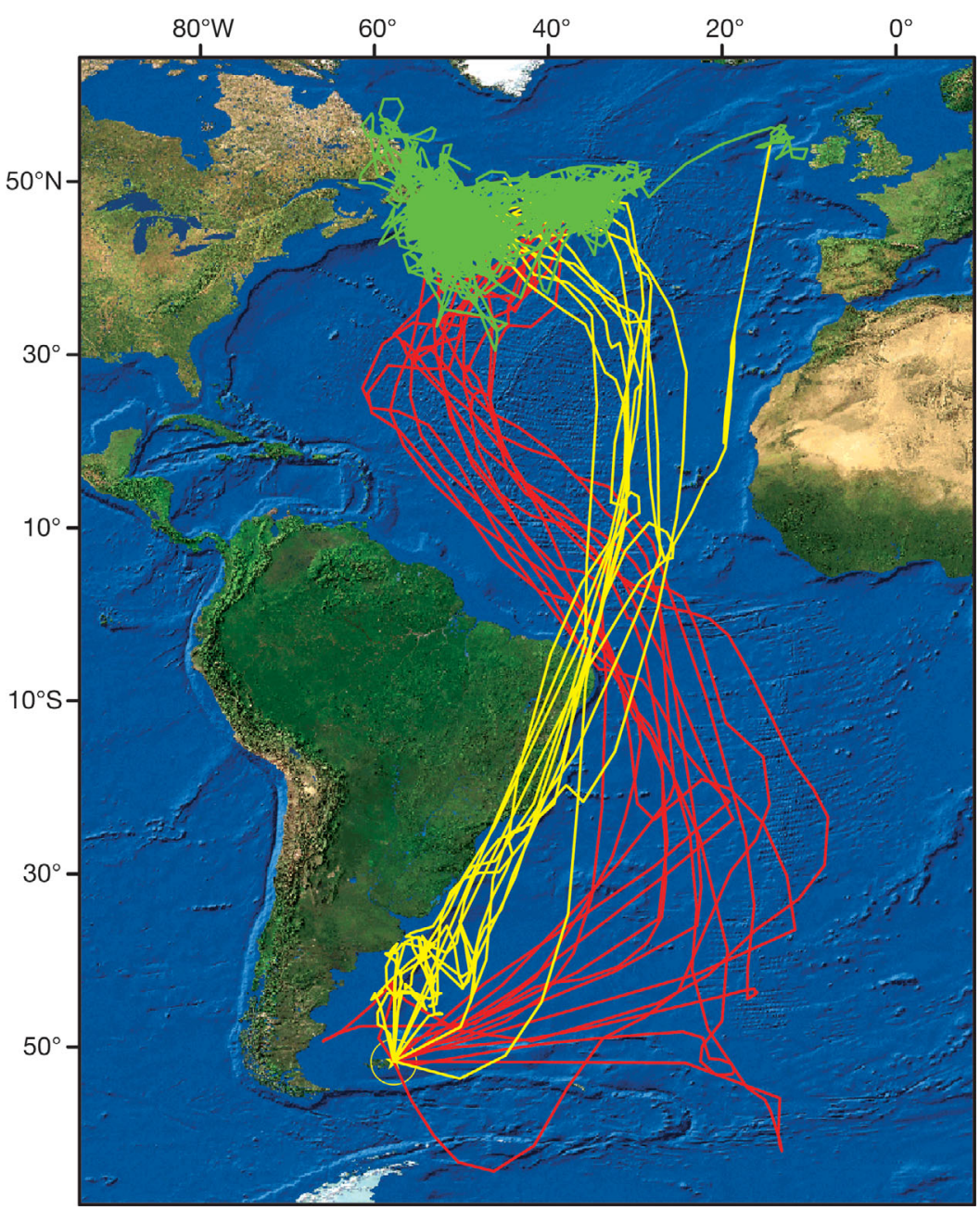

Fig. 2. Puffinus griseus. Trans-equatorial migration and nonbreeding distribution of sooty shearwaters from Kidney Island, Falklands Islands, South Atlantic in 2008 and 2009. Red depicts the northward migration, green the main staging and nonbreeding areas and yellow depicts the southward migration

\section{Migration and nonbreeding season strategies}

Failed breeders ( $\mathrm{n}=3$; Birds 6095, 6093, 6083) departed Kidney Island for the season on average $12 \mathrm{~d}$ earlier than presumed successful breeders $(n=14)$ of the same year (Table 1). Birds commenced transequatorial migration on a mean date of 27 March ( $\pm 9 \mathrm{~d}$, range 9 March to 12 April, $\mathrm{n}=22$; Table 1), heading rapidly northeast from the colony to between 8 and $30^{\circ} \mathrm{W}$, northwest from $\sim 30^{\circ} \mathrm{S}$ to $30^{\circ} \mathrm{N}$, and finally northeast again before settling in the northern hemisphere on 17 April ( \pm 7 d, 8 to 29 April, $\mathrm{n}=21$; Table 1 and Fig. 2). Birds covered an average $15696 \pm 1885 \mathrm{~km}$ (12885 to $19308 \mathrm{~km}, \mathrm{n}=18)$ in $21 \pm$ $5 \mathrm{~d}$ (15 to $34 \mathrm{~d}, \mathrm{n}=21$; Table 1 ) on their northward migration, at an average speed of $753 \pm 130 \mathrm{~km} \mathrm{~d}^{-1}$ (568 to $975 \mathrm{~km} \mathrm{~d}^{-1}, \mathrm{n}=18$ ). Ten birds made a single stopover on the trip north (Bird 6095 stopped twice), either near the start of migration in the southern South Atlantic ( 2 to $25^{\circ} \mathrm{W}, 40$ to $60^{\circ} \mathrm{S}$; duration $=3$ to $9 \mathrm{~d}$, $\mathrm{n}=6$ ) or near the end, in the northwest Atlantic ( 47 to $58^{\circ} \mathrm{W}, 29$ to $45^{\circ} \mathrm{N}$; duration 2 to $12 \mathrm{~d}, \mathrm{n}=5$ ).

Sooty shearwaters spent the austral winter exclusively in the North Atlantic in 2008 and 2009, and were distributed largely north of $40^{\circ} \mathrm{N}$ from arrival in mid April until their return in early September, $143 \pm 10$ d later (Fig. 2). Core areas (40\% kernels) included deep pelagic waters west of the MAR where birds staged on first arrival, and the shallower continental shelf waters of the eastern Canadian Grand Bank where they resided for the northern summer (Fig. 3a). The 2 distinct cores reflect progression of bird movement over time. Most commonly, birds (72\%; 13 of 18 birds) staged west of the MAR $\left(\sim 43\right.$ to $55^{\circ} \mathrm{N}, \sim 32$ to $43^{\circ} \mathrm{W}$ ) from mid April to early June (resi-

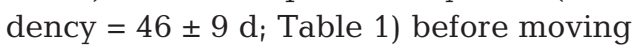
into shallower waters of the Grand Bank and the Newfoundland and Labrador shelves $\left(98 \pm 10 \mathrm{~d}_{i}\right.$ Table 1 and Birds 6073, 6092, 6076 and 3623 in Fig. 3b). Five birds $(28 \%)$ spent little or no time at the MAR, instead staging in pelagic waters south of the Grand Bank before moving onto the Bank itself $\left(132 \pm 11 \mathrm{~d}_{\text {; }}\right.$ Table 1 and Birds 6095 and 6085 in Fig. 3b). A single female (Bird 6091 in Fig. $3 b$ ) resided in the vicinity of the MAR 

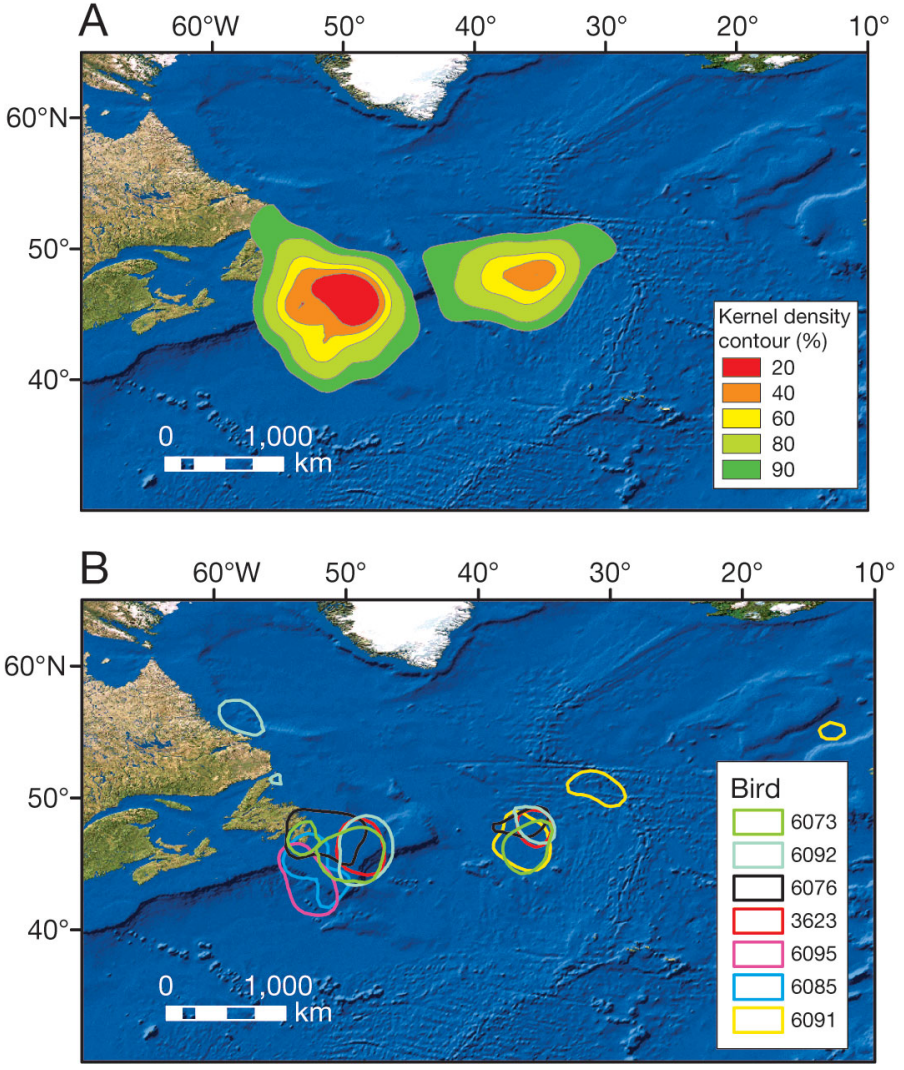

Fig. 3. Puffinus griseus. (A) Kernel density distribution of sooty shearwaters in the North Atlantic during the 2008 and 2009 nonbreeding periods. (B) $40 \%$ kernel density contours designating core areas of 7 representative individuals

for $123 \mathrm{~d}$ before moving to the Ireland/Rockall Trench in the northeast Atlantic in mid August, a few weeks before migrating south.

Birds commenced southward migration on 6 September $( \pm 6 d, 26$ August to 19 September, $\mathrm{n}=19$; Table 1), heading east/southeast to $\sim 28$ to $30^{\circ} \mathrm{W}$ and then directly south-southwest toward South America, where they then travelled parallel to the coastline. The return leg of the figure-of-eight migration took $21 \pm 4$ days (12 to $28 \mathrm{~d}, \mathrm{n}=19$; Table 1 ), with birds

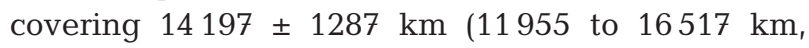
$\mathrm{n}=12$; Table 1) at an average travelling speed of $682 \pm 129 \mathrm{~km} \mathrm{~d}^{-1}$ (534 to $996 \mathrm{~km} \mathrm{~d}^{-1}, \mathrm{n}=12$ ). The total distance travelled during southward migration was significantly less than on the trip north (paired $t$-test: $t_{9}=2.79, \mathrm{p}=0.021$ ). Following the strongly directed movement south, the return migration included an approximately week-long terminal stopover off South America ( $6 \pm 4.0 \mathrm{~d}, 4$ to $12 \mathrm{~d}$ ) for the majority of birds $(79 \%$; 15 of 19) immediately prior to returning to the colony (Fig. 2). For 8 birds with spatial data, this stopover was centered between 35 and $46^{\circ} \mathrm{S}$;
5 birds used pelagic waters in the Argentine Basin, 4 used waters over the Northern Patagonian Shelf near Rio de la Plata, Argentina, and 1 bird moved between these areas (Fig. 2). For 4 birds whose southward migration was continuous, the journey back to the Falklands from the North Atlantic was completed, on average, in just $15.5 \mathrm{~d}$ (12 to $18 \mathrm{~d}$ ). Birds first returned to the colony on 28 September $( \pm 7 \mathrm{~d}, 13$ September to 11 October, $\mathrm{n}=19$; Table 1). On average males returned $9 \mathrm{~d}$ earlier than females (independent samples $t$-test: $t_{16}=-2.59, \mathrm{p}=0.020$ ).

Loggers were recovered from 4 birds tracked in both the 2008 and 2009 nonbreeding periods; for 2 birds (6092 and 3622) tracks were complete while partial information was obtained for the others (6075 and 6079). For 3 of the 4 birds, departure date of the northward migration was very similar between years; however, the migration of Bird 6079 started 12 d later in 2009 than in 2008 (Table 1). For 2 of 3 birds, the duration and routes of (northerly) migration were similar between years, as was the residency period in the North Atlantic. For Bird 6075, however, migration was 10 d longer in 2008 than in 2009 due to an extended stopover south of the Grand Bank in the first year. Bird 6092 had slightly different residency patterns in the 2 years; in August 2008 foraging was concentrated over the Labrador Shelf, whereas in August 2009 this bird foraged on the Grand Bank. Interestingly, in both years, Bird 6092 stopped for $\sim 9 \mathrm{~d}$ in the southern South Atlantic at $\sim 6$ to $12^{\circ} \mathrm{W}$ during the northward migration.

\section{Activity patterns}

Overall during northward and southward migrations, sooty shearwaters spent a high proportion of the day $\left(78.4 \pm 4.2 \% ; 10.1 \pm 0.7 \mathrm{~h} \mathrm{~d}^{-1}\right)$ and over half of the night $\left(58.5 \pm 9.1 \% ; 6.4 \pm 1.0 \mathrm{~h} \mathrm{night}^{-1}\right)$ flying, and comparatively little time on or under the sea surface (Table 2). Patterns of activity during the active commuting and stopover days of migration were, however, very different. When commuting, birds spent $83.2 \pm 4.3 \%$ of the day and $68.0 \pm 5.7 \%$ of the night flying; both values are significantly higher than the respective values on stopover days $(60.9 \pm 14.8 \%$ and $20.3 \pm 12.9 \%$; Wilcoxon signed-ranks tests: $Z=-3.24$, $\mathrm{p}<0.01$, and $Z=-3.41, \mathrm{p}<0.01)$. During active migration, all birds spent 3 to 6 consecutive days flying in excess of $85 \%$ of the day and the night. After arriving in the northern hemisphere, activity patterns were very different (Table 2). Birds spent 70.2 $\pm 5.6 \%$ $\left(11.1 \pm 0.8 \mathrm{~h} \mathrm{~d}^{-1}\right)$ of the day, and $89.8 \pm 4.3 \%(7.1 \pm$ 
Table 2. Puffinus griseus. Activity patterns of sooty shearwaters, as recorded by BAS geolocators, during the migration and during the residency period in the northern hemisphere. Values are means of individual bird means $\pm 1 \mathrm{SD}$, with the range for individuals in parentheses

\begin{tabular}{|c|c|c|c|c|}
\hline & All days & $\begin{array}{l}\text { Migration (north \& south } \\
\text { Commuting days }\end{array}$ & Stopover days & $\begin{array}{l}\text { Northern hemisphere } \\
\text { residency period }\end{array}$ \\
\hline \multicolumn{5}{|c|}{ Time on water (\%) during: } \\
\hline Daylight & $21.6 \pm 4.2(15.3-29.0)$ & $16.8 \pm 4.3(11.7-29.2)$ & $39.1 \pm 14.8(9.2-60.7)$ & $70.2 \pm 5.6(59.4-78.9)$ \\
\hline Darkness & $41.5 \pm 9.1(19.5-55.2)$ & $32.0 \pm 5.7(19.5-39.4)$ & $79.7 \pm 12.9(49.3-95.6)$ & $89.8 \pm 4.3(83.0-96.2)$ \\
\hline \multicolumn{5}{|c|}{ Time flying (\%) during: } \\
\hline Daylight & $78.4 \pm 4.2(71.0-84.7)$ & $83.2 \pm 4.3(70.8-88.3)$ & $60.9 \pm 14.8(39.3-90.8)$ & $29.8 \pm 5.6(21.1-40.6)$ \\
\hline Darkness & $58.5 \pm 9.1(44.8-80.5)$ & $68.0 \pm 5.7(60.6-80.5)$ & $20.3 \pm 12.9(4.4-50.7)$ & $10.2 \pm 4.3(3.8-17.0)$ \\
\hline \multicolumn{5}{|c|}{ Total time on water $(\mathrm{h})$ : } \\
\hline Daylight & $2.8 \pm 0.5(2.0-3.8)$ & $2.2 \pm 0.6(1.5-3.8)$ & $5.0 \pm 1.9(1.2-7.9)$ & $11.1 \pm 0.8(9.4-12.3)$ \\
\hline Darkness & $4.4 \pm 0.9(2.2-5.7)$ & $3.4 \pm 0.6(2.2-4.1)$ & $8.5 \pm 1.3(5.6-10.2)$ & $7.1 \pm 0.3(6.5-7.6)$ \\
\hline \multicolumn{5}{|c|}{ Total time in flight (h): } \\
\hline Daylight & $10.1 \pm 0.7(8.8-11.1)$ & $10.7 \pm 0.6(9.0-11.5)$ & $7.9 \pm 2.0(5.1-12.2)$ & $4.6 \pm 0.9(3.2-6.3)$ \\
\hline Darkness & $6.4 \pm 1.0(4.8-8.7)$ & $7.4 \pm 0.7(6.6-8.7)$ & $2.2 \pm 1.5(0.5-5.7)$ & $0.9 \pm 0.4(0.3-1.5)$ \\
\hline
\end{tabular}

$0.3 \mathrm{~h} \mathrm{night}^{-1}$ ) of the night sitting on the water (Table 2). Broad scale activity patterns were similar between the sexes (Mann-Whitney $U$ tests, $\mathrm{p}>0.05$ for all parameters), across individuals and through time while birds were resident in the North Atlantic.

\section{Habitat associations during the nonbreeding period}

On arrival in the northern hemisphere, birds staged in deep pelagic areas either west of the MAR (mean depth 4281 and $4341 \mathrm{~m}$ in the $20 \%$ and 20 to $40 \%$ kernel regions, respectively), in waters that were moderately warm and productive (mean SST 11.9 and $12.3^{\circ} \mathrm{C}$, chl $a=0.82$ and $0.69 \mathrm{mg} \mathrm{m}^{-3}$, respectively), or south of the Newfoundland Grand Bank (mean depth 3239 and $2752 \mathrm{~m}$ in the $20 \%$ and 20 to $40 \%$ kernel regions, respectively) in slightly cooler waters that were relatively more productive (mean SST 9.2 and $8.5^{\circ} \mathrm{C}$, chl $a=1.28$ and $1.04 \mathrm{mg} \mathrm{m}^{-3}$, respectively; Table 3). During May, bathymetric and oceanographic characteristics were similar among different portions of the utilization distribution (defined by the kernel density contours) at both staging areas. In July, when birds were resident on the Grand Bank, core areas were shallow (mean depth 115 and $136 \mathrm{~m}$ in the $20 \%$ and 20 to $40 \%$ kernel regions, respectively), and warm (mean SST 13.2 and $13.1^{\circ} \mathrm{C}$, respectively) with relatively low productivity (chl $a=0.26$ and $0.33 \mathrm{mg} \mathrm{m}^{-3}$, respectively; Table 3). More peripheral areas were both deeper and warmer than core areas, but in mid-summer the whole range was similar in terms of productivity (Table 3).

\section{Stable isotope analysis}

Mean $\delta^{15} \mathrm{~N}$ and $\delta^{13} \mathrm{C}$ values in the primary feathers of sooty shearwaters were $13.4 \pm 1.8 \%$ (range 10.6 to $16.1 \%$, $\mathrm{n}=25)$ and $-18.9 \pm 0.5 \%$ о $(-20.6$ to $-17.8 \%$, $\mathrm{n}=25)$, respectively. Feathers were collected from

Table 3. Puffinus griseus. Bathymetric and oceanographic characteristics within the kernel density distribution of sooty shearwaters while resident on the nonbreeding grounds, May and July 2008. MAR: Mid-Atlantic Ridge

\begin{tabular}{|c|c|c|c|c|c|c|c|c|c|}
\hline \multirow[t]{3}{*}{ Kernel } & \multicolumn{3}{|c|}{ Water depth (m) } & \multicolumn{3}{|c|}{ Sea surface temperature $\left({ }^{\circ} \mathrm{C}\right)$} & \multicolumn{3}{|c|}{ Chlorophyll a concentration $\left(\mathrm{mg} \mathrm{m}^{-3}\right)$} \\
\hline & & & - July — & & & - July - & -Ma & & - July \\
\hline & $\begin{array}{l}\text { West of } \\
\text { MAR }\end{array}$ & $\begin{array}{c}\text { South of } \\
\text { Grand Bank }\end{array}$ & $\begin{array}{l}\text { Grand } \\
\text { Bank }\end{array}$ & $\begin{array}{l}\text { West of } \\
\text { MAR }\end{array}$ & $\begin{array}{c}\text { South of } \\
\text { Grand Bank }\end{array}$ & $\begin{array}{c}\text { Grand } \\
\text { Bank }\end{array}$ & $\begin{array}{l}\text { West of } \\
\text { MAR }\end{array}$ & $\begin{array}{c}\text { South of } \\
\text { Grand Bank }\end{array}$ & $\begin{array}{l}\text { Grand } \\
\text { Bank }\end{array}$ \\
\hline $0-20 \%$ & $4281 \pm 259$ & $3239 \pm 1135$ & $115 \pm 34$ & $11.9 \pm 0.9$ & $9 \quad 9.2 \pm 1.9$ & $13.2 \pm 0.9$ & $0.82 \pm 0.24$ & $1.28 \pm 0.67$ & $0.26 \pm 0.06$ \\
\hline $20-40 \%$ & $4341 \pm 245$ & $2752 \pm 2037$ & $136 \pm 62$ & $12.3 \pm 1.0$ & $0 \quad 8.5 \pm 3.1$ & $13.1 \pm 1.1$ & $0.69 \pm 0.29$ & $1.04 \pm 0.76$ & $0.33 \pm 0.16$ \\
\hline $40-60 \%$ & $4315 \pm 257$ & $2499 \pm 2138$ & $296 \pm 438$ & $12.2 \pm 1.1$ & $18.6 \pm 4.7$ & $12.8 \pm 1.6$ & $0.87 \pm 0.41$ & $1.34 \pm 2.11$ & $0.37 \pm 0.28$ \\
\hline $60-80 \%$ & $4198 \pm 286$ & $2600 \pm 2148$ & $1020 \pm 1211$ & $12.2 \pm 1.6$ & $6 \quad 8.2 \pm 6.1$ & $14.2 \pm 2.3$ & $0.77 \pm 0.25$ & $1.52 \pm 3.26$ & $0.36 \pm 0.83$ \\
\hline $80-90 \%$ & $4041 \pm 405$ & $2796 \pm 2206$ & $2507 \pm 1563$ & $12.6 \pm 1.4$ & $4 \quad 8.8 \pm 7.1$ & $16.6 \pm 3.2$ & $0.79 \pm 0.28$ & $0.92 \pm 1.39$ & $0.29 \pm 0.17$ \\
\hline
\end{tabular}


5 birds whose loggers failed, so the sample size for isotope analysis exceeded that for spatial data. Restricting the comparison to 2008 when the bulk of feathers $(n=21)$ were collected, isotope values were similar between the sexes $\left(t_{16}=0.89, \mathrm{p}=0.40\right.$ for $\delta^{15} \mathrm{~N}$ and $t_{16}=0.32, \mathrm{p}=0.76$ for $\delta^{13} \mathrm{C}$ ), but differed according to staging location (for birds with corresponding spatial data). Birds that staged near the MAR had significantly lower $\delta^{15} \mathrm{~N}(12.5 \pm 1.1 \%, \mathrm{n}=12)$ and higher $\delta^{13} \mathrm{C}$ values $(-18.6 \pm 0.3 \%, \mathrm{n}=12)$ than birds that staged south of the eastern Canadian Grand Bank $\left(\delta^{15} \mathrm{~N}=15.7 \pm 0.3 \%\right.$, $\mathrm{n}=5$, and $\delta^{13} \mathrm{C}=-19.1 \pm 0.3 \%$, $\mathrm{n}=5$; Mann-Whitney $U=0.00, \mathrm{df}=1, \mathrm{p}<0.01$; independent samples $t$-test $t_{15}=2.8, \mathrm{p}<0.05$ : Fig. 4 ). The mean $\delta^{15} \mathrm{~N}$ difference $(3.2 \%)$ between regions is equivalent to approximately 0.89 trophic levels, assuming an average enrichment of $3.6 \%$ between adjacent trophic levels (Fry 1988).

\section{DISCUSSION}

This study is the first to reveal details of the spectacular migration that annually sees millions of southern hemisphere Puffinus shearwaters flood the productive waters of the northwest Atlantic, to become the primary avian consumers of fish during the northern summer (Barrett et al. 2006). While it has long been known that both adults and immatures of the more numerous great shearwater migrate to the North Atlantic (Brown 1988), we confirm this also to be the case for adult sooty shearwaters breeding in the Atlantic (cf. Brown 1988, Cooper et al. 1991).

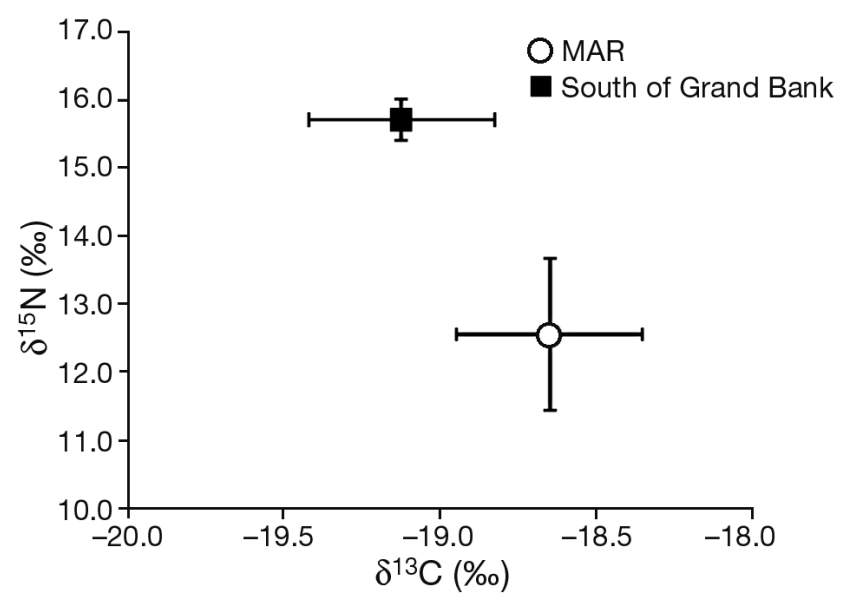

Fig. 4. Puffinus griseus. Mean $( \pm \mathrm{SD}) \delta 15 \mathrm{~N}$ and $\delta 13 \mathrm{C}$ values in primary feathers of sooty shearwaters grown during the 2008 post-breeding period by individuals that staged at the Mid-Atlantic Ridge (MAR) and south of Grand Bank in eastern Canadian waters off Newfoundland
Sooty shearwaters are the only shearwater species that breeds in both the South Atlantic and South Pacific, and the adults are now known to be transequatorial migrants in both basins (Shaffer et al. 2006, present study).

In the Atlantic, sooty shearwaters are highly migratory, switching hemispheres between breeding and nonbreeding seasons to exploit productive foraging sites in the South and North Atlantic, respectively; sites that are used by a diversity of top predators year-round (Croxall \& Wood 2002, Barrett et al. 2006, Phillips et al. 2006, Guilford et al. 2009, Hedd et al. 2011). After departing the breeding grounds, the shearwaters commence a rapid northward migration that is followed by an extended period of residence $(143 \pm 10 \mathrm{~d})$ in the North Atlantic. The temporal pattern, movement trajectory and extended northern hemisphere residence of birds in the Atlantic was very similar to patterns reported for this species in the Pacific (Shaffer et al. 2006). Interestingly, there was good correspondence between migration parameters of sooty shearwaters and some of the Arctic terns Sterna paradisaea migrating between Greenland and the Brazilian coast (Egevang et al. 2010). Timing of departure on both northern and southern migrations were similar, and routes were over deep water and sigmoidal, running counter clockwise around the South Atlantic and clockwise around the North Atlantic gyres, presumably as birds utilized global wind patterns (Egevang et al. 2010). Studies combining individual bird movement data with synoptic near-surface winds have demonstrated that the trans-equatorial migration of shearwaters, and probably other long-distance seabird migrants, in the Atlantic and Pacific are at least partially assisted by global wind circulation patterns (Felicísimo et al. 2008, González-Solís et al. 2009).

Given their low dive frequency, Shaffer et al. (2006) suggested that sooty shearwaters fed little as they migrated through the Pacific Ocean. Rapid migrations, coupled with the fact that birds spent the bulk of their time on the wing, also suggest that sooty shearwaters feed little when actively migrating through the Atlantic. Contrasting activity patterns during commuting and stopover days of migration, however, suggest that the latter may represent time spent feeding, as hypothesized for Manx Puffinus puffinus (Guilford et al. 2009) and Cory's shearwaters (Dias et al. 2011), 2 other long-distance transequatorial migrants. For sooty shearwaters, stopovers occurred mainly near the end of large-scale directional movements, the most important being the terminal stop in waters of the Northern Patagonian 
Shelf and Argentine Basin near the end of the southward migration. For Cory's shearwaters, most (70\%) stopovers occurred within the populations' known wintering areas (Dias et al. 2011), whereas those of the Manx shearwater occurred regularly along the migration route (Guilford et al. 2009). Perhaps this difference suggests more frequent need for refueling in the smaller Manx shearwater. During stopovers, sooty shearwaters flew for $61 \%$ of the day and just $20 \%$ of the night which is consistent with expectations for diurnal foragers (Shaffer et al. 2009) and similar to stopover behavior of Cory's shearwaters, which flew for 48 and $18 \%$ of the day and night, respectively (Dias et al. 2011). With the exception of streaked shearwaters Calonectris leucomelas which averaged 34 to $66 \%$ of total migration time in flight (Yamamoto et al. 2010), and Guilford et al.'s (2009) study of migration stopovers by Manx shearwaters, how shearwaters apportion their time during migration is poorly known. Compared with some larger Procellariiformes, migrating sooty shearwaters were more diurnally active $(78 \%$ of the day in flight, overall) than wandering Diomedea exulans (66\%) and light-mantled albatrosses Phoebetria palpebrata $(75 \%)$, but somewhat less active than black-browed albatrosses Thalassarche melanophris (82\%), greyheaded albatrosses T. chrysostoma (89\%) and whitechinned petrels (85\%; Mackley et al. 2010, 2011). At night, however, migrating sooty shearwaters were more active (59\% of the night in flight, overall) than all the albatrosses ( 27 to $56 \%$ ), and only less active than the highly nocturnal white-chinned petrels (70\%; Mackley et al. 2010, 2011). To our knowledge, Dias et al.'s (2011) Cory's shearwater study is the only other to report activity patterns during migration separately for stopover and active commuting days. During active migration, Cory's shearwaters flew for $67 \%$ of the day and $45 \%$ of the night, compared with respective values of 83 and $68 \%$ for sooty shearwaters in this study. The high degree of nocturnal activity of sooty shearwaters is notable, and could help explain the rapid transit rates reported in other studies of shearwaters during trans-equatorial migration (Shaffer et al. 2006, Guilford et al. 2009).

While broadly similar in terms of trajectory, there are at least 2 striking differences in the migration patterns of sooty shearwaters in the Atlantic and Pacific Oceans. First, cumulative round-trip migration distances of birds in the Pacific were double those in the Atlantic (64 000 vs. $~ 30000$ km; Shaffer et al. 2006), presumably due to the more narrow aspect of the Atlantic basin. Second, with the exception of a single individual that spent part of the non- breeding period in the northeast Atlantic, sooty shearwaters from Kidney Island showed strong migratory connectivity (Webster et al. 2002), settling in a single area in the northwest Atlantic (the Grand Bank) for the bulk of the austral winter; a pattern that was repeated by at least 2 individuals in successive years. Sooty shearwaters from 2 breeding colonies in the Pacific mixed on the nonbreeding grounds and used 3 discrete areas (off Japan, Alaska and California), with no movement of individuals between areas (Shaffer et al. 2006). Such differences have conservation implications as presumably avian populations with weaker migratory connectivity (e.g. south polar skua Catharacta maccormicki; Kopp et al. 2011) or those in which at least some individuals show flexibility among years in winter destinations (e.g. Cory's shearwaters; Dias et al. 2011) would be better able to buffer any anthropogenic threats or disruptions in food supply encountered on the wintering grounds (Webster et al. 2002, González-Solís et al. 2007, Kopp et al. 2011). In the Pacific, sooty shearwater populations are declining (Veit et al. 1996, 1997, Lyver et al. 1999, Scott et al. 2008), but there is no information on their status in the Atlantic.

This study has identified the pelagic area west of the MAR ( $\sim 3$ to $55^{\circ} \mathrm{N}, \sim 32$ to $43^{\circ} \mathrm{W}$ ) as an important staging area for sooty shearwaters at the end of their northward migration. We hypothesize this to be an important moulting location, supported by a number of lines of evidence, perhaps most convincingly the difference in isotope signatures of birds staging near the MAR and south of the eastern Canadian Grand Bank (Fig. 4). In the North Pacific, sooty shearwaters undergo a complete postnuptial primary moult between May and August (Marchant \& Higgins 1990), with rapid wing moult observed off both California and British Columbia in May and June (Brown 1988). Moulting sooty shearwaters, however, are not seen during summer in eastern Canadian waters; shipboard observations are almost always of birds with a complete set of fresh, unabraded flight feathers (Brown 1988). Different observations in these ocean basins led Brown (1988) to suggest that the North Atlantic sooty shearwater population likely consisted of immature birds, and that adults breeding in the South Atlantic likely migrated into the Pacific. We confirm migration of adults into the North Atlantic and suggest that moulting sooty shearwaters are not seen off eastern Canada, as along coasts in the Pacific, because they moult upon arrival in the northern hemisphere when most birds stage far from shore west of the MAR. Using digital photography, Keijl (2011) reported active primary moult in $60 \%$ 
(16 of 25) of post-juvenile sooty shearwaters observed in the northeast Atlantic in mid-July; the remainder had either already completed or not yet started their moult. The absence of moult records from both historic and recent shipboard observations off eastern Canada (C. Gjerdrum, Environment Canada pers. comm.) could be explained if (1) adult wing moult was largely complete by the time birds moved onto the Grand Bank in early June, (2) outer primary moult is difficult to observe from vessels, or (3) fresh plumaged juveniles regularly occur in the area. Spring vessel surveys in the vicinity of the MAR would help clarify moult patterns.

The minority of shearwaters that did not stage at the MAR presumably moulted flight feathers south of the Grand Bank. Our feather analyses show that these birds feed at a higher trophic level and on a more specialized diet. After adjusting for diet-feather fractionation $\left(4.2 \pm 0.7 \%\right.$ o for $\delta^{15} \mathrm{~N}_{\text {; }}$ Cherel et al. 2005), the average corrected $\delta^{15} \mathrm{~N}$ feather value for these birds of $11.5 \%$ o (range 11.0 to $11.8 \%$ ), and the limited individual variation, suggests a specialized diet comprised of mid-trophic level prey, perhaps capelin Mallotus villosus $\left(\delta^{15} \mathrm{~N}=10.2\right.$ to $12.2 \%$; Davoren et al. 2002, Sherwood \& Rose 2005) or other pelagic fishes. Capelin is the principal forage species on the Grand Bank, and during spring and early summer it migrates from over-wintering areas near the edge of the continental shelf to the coastal waters of Newfoundland to spawn (Nakashima 1992). Birds at the MAR were feeding at a lower average trophic level (mean average corrected feather $\delta^{15} \mathrm{~N}=8.4 \%$, range 6.6 to $10.8 \%$ ), probably on pelagic zooplankton, and consuming a wider variety of prey items. Mixed diets dominated by zooplankton are not unexpected. Multi-year studies of sooty shearwaters wintering in the Bay of Fundy, Canada have shown extensive feeding on northern krill Meganyctiphanes norvegica, Atlantic herring Clupea harengus and northern short-fin squid Illex illecebrosus (Brown et al. 1981, Ronconi et al. 2010).

Sooty shearwaters from Kidney Island settled in a single, relatively restricted area over the eastern Canadian Grand Bank for much of the nonbreeding period (early June to early September). The Grand Bank is a productive region that provides important habitat for a diversity of large vertebrate predators throughout the year. Globally significant concentrations of marine birds include over-wintering thickbilled murres Uria lomvia, common murres $U$. aalge and dovekies Alle alle. In summer, the area supports large breeding concentrations of auks and Leach's storm-petrels Oceanodroma leucorhoa, and hosts migrant Puffinus shearwaters and storm-petrels from the southern hemisphere (Barrett et al. 2006). The low productivity in the area in midsummer (July) reflects the seasonal cycle of energy transfer, as high spring primary productivity is converted into the zooplankton and fish consumed by top predators. After reaching the North Atlantic, sooty shearwaters greatly reduced their activity levels, flying on average for only $30 \%$ of the day and $10 \%$ of the night throughout the residence period. This is similar to reports for Cory's shearwaters who, depending on wintering area, spent 67 to $79 \%$ of their time on the water (Catry et al. 2011), and may reflect either (or both) a seasonal reduction in energy requirements or favorable foraging conditions, such that birds do not need to travel far to find food. Wedge-tailed shearwaters Puffinus pacificus spent $57 \%$ of the day and $86 \%$ of the night on the water (Catry et al. 2009), whereas wintering streaked shearwaters sat on the water $74 \%$ of the time (Yamamoto et al. 2010). For the tropical species, largely diurnal activity of wedge-tailed and increased dawn and dusk activity of streaked shearwaters is the likely result of feeding in association with subsurface predators (Catry et al. 2009, Yamamoto et al. 2010). Interestingly, sooty shearwaters spent higher proportions of both the day and the night on the water during winter than did wandering, light-mantled, black-browed or greyheaded albatrosses, or white-chinned petrels (Mackley et al. 2010, 2011), providing further evidence of favourable foraging conditions on the Grand Bank.

Recent remote tracking of seabirds and other top predators has identified the pelagic area west of the MAR as an important area for a diversity of northern and southern hemisphere breeders at different stages of their annual cycles and at different times of the year. During the northern spring, this is an important staging area for thick-billed murres (breeding at the Gannet Islands, Labrador and the Minarets, Nunavut) that use the area in March to April before returning to Arctic breeding colonies (McFarlane Tranquilla et al. unpubl. data), and for both postbreeding sooty shearwaters and south polar skuas following trans-equatorial migrations from the South Atlantic (present study, Kopp et al. 2011). Sooty shearwaters use the area from late April to early June (present study), whereas skuas are resident from late May to early September (Kopp et al. 2011). In late summer and fall, breeding Cory's shearwaters use the area on long foraging trips during the chick-rearing period (Magalhães et al. 2008, Paiva et al. 2010), Arctic terns stop in the area for $\sim 24 \mathrm{~d}$ beginning in mid to late August (Egevang et al. 2010), and post- 
breeding long-tailed skuas Stercorarius longicaudus stage in the region for 1 to $3 \mathrm{wk}$ in August to September (Sittler et al. 2011). In winter, dovekies, and black-legged kittiwakes Rissa tridactyla from Norway and Scotland, also use the area, in October to March (Mosbech et al. 2012) and September to February (Bogdanova et al. 2011, González-Solís et al. 2011), respectively. Boertmann (2011) travelled through the area by vessel in mid September 2006 and observed high densities of Leach's storm-petrels, long-tailed skuas and Arctic terns, confirming tracking results for the latter 2 species. Atlantic bluefin tuna Thunnus thynnus use the area extensively, particularly in summer (Walli et al. 2009). Using residency patterns from a diversity of tracked top predators, Wakefield et al. (2011) described the spatial extent and likely oceanographic drivers of this newly described seabird diversity hotspot.

Oceanographically, the area is in the vicinity of the Sub-Polar Front, which separates cool, productive, lower salinity sub-Arctic waters from warmer, less productive, higher salinity waters of the central North Atlantic (Søiland et al. 2008, Boertmann 2011). High regional variability in salinity and SST suggests high eddy variability and mixing of the different water masses (Søiland et al. 2008, Boertmann 2011). Opdal et al. (2008) suggested that the interaction between topographical features, circulation and primary production near the front appeared to create favorable conditions for many taxa across trophic levels. The North Pacific transition zone provides an interesting comparison and potential scope for comparative studies across the Atlantic and Pacific basins. The North Pacific transition zone also encompasses an abrupt north-to-south transition between sub-Arctic and sub-tropical waters with dynamic frontal regions (Polovina et al. 2001), and attracts a diversity of predatory marine vertebrates throughout the year (Kobayashi et al. 2008, Kappes et al. 2010, Block et al. 2011). In 2010, the OSPAR Convention for the Protection of the Marine Environment of the North-East Atlantic designated the Charlie Gibb's Fracture Zone as one of the first pelagic marine protected areas (see www.ospar.org/html_documents/ ospar/news/ospar_pr_10_mm2010_en.pdf). Regular use of the adjacent area west of the MAR by a diversity of top predators throughout the year suggests that this region too could benefit from designation, and consequent management and protection (see also Wakefield et al. 2011). Tracking of seabirds and other top predators is a highly effective method for identifying important marine areas, particularly in the pelagic zone, where more traditional techniques (e.g. ship-based research) are logistically complicated and consequently rare. Predator tracking is providing the foundation for ongoing global efforts to reach the World Summit on Sustainable Development and the Convention on Biological Diversity goal of implementing representative systems of marine protected areas by 2012 .

Acknowledgements. We thank the Falkland Islands Government for granting Research Licenses and Visitor access permits to Kidney Island and Memorial University's Institutional Animal Care Committee for granting approval for the protocols used in this study. We are grateful to Robin Snape, Anton Wolfaardt and Alastair Baylis for help retrieving loggers, and Falklands Conservation and Sally Poncet for providing us with field supplies and equipment. We also thank Paul Regular, who wrote R code to process and summarize the logger immersion data. This project was supported by an NSERC Discovery Grant and the Government of Canada's Program for International Polar Year to W.A.M. This research represents a contribution to the British Antarctic Survey Ecosystems Programme.

\section{LITERATURE CITED}

Barrett RT, Chapdelaine G, Anker-Nilssen T, Mosbech A, Montevecchi WA, Reid JB, Veit RR (2006) Seabird numbers and prey consumption in the North Atlantic. ICES J Mar Sci 63:1145-1158

Block BA, Jonsen ID, Jorgensen SJ, Winship AJ and others (2011) Tracking apex marine predator movements in a dynamic ocean. Nature 975:86-90

Boertmann D (2011) Seabirds-at-sea in the central north Atlantic, September 2006, evidence for an oceanic seabird hot-spot. Mar Ornithol 39:83-88

Bogdanova MI, Daunt F, Newell M, Phillips RA, Harris MP, Wanless S (2011) Seasonal interactions in the blacklegged kittiwake, Rissa tridactyla: links between breeding performance and winter distribution. Proc Biol Sci 278:2412-2418

Brooke M (1990) The Manx shearwater. T \& AD Poyser, London

Brooke M (2004) Albatrosses and petrels across the world. Oxford University Press, Oxford

Brown RGB (1988) The wing moult of fulmars and shearwaters (Procellariidae) in Canadian Atlantic waters. Can Field Nat 102:203-208

Brown RGB, Barker SP, Gaskin DE, Sandeman MR (1981) The foods of great and sooty shearwaters Puffinus gravis and $P$. griseus in eastern Canadian waters. Ibis 123:19-29

> Catry T, Ramos JA, Le Corre M, Phillips RA (2009) Movements, at-sea distribution and behavior of a tropical pelagic seabird: the wedge-tailed shearwater in the western Indian Ocean. Mar Ecol Prog Ser 391:231-242

> Catry P, Dias MP, Phillips RA, Granadeiro JP (2011) Different means to the same end: long-distance migrant seabirds from two colonies differ in behavior, despite common wintering grounds. PLoS One 6:e26079

Cherel Y, Hobson KA, Hassani S (2005) Isotopic discrimination between food and blood and feathers of captive penguins: implications for dietary studies in the wild. Physiol Biochem Zool 78:106-115 
Cooper J, Underhill LG, Avery G (1991) Primary molt and transequatorial migration of the sooty shearwater. Condor 93:724-730

Croxall JP, Wood AG (2002) The importance of the Patagonian Shelf for top predator species breeding at South Georgia. Aquat Conserv 12:101-118

Croxall JP, Silk JRD, Phillips RA, Afanasyev V, Briggs DR (2005) Global circumnavigations: tracking year-round ranges of nonbreeding albatrosses. Science 307:249-250

> Davoren GK, Montevecchi WA, Anderson JT (2002) Scaledependent associations of predators and prey: constraints imposed by flightlessness of common murres. Mar Ecol Prog Ser 245:259-272

> Dias MP, Granadeiro JP, Phillips RA, Alonso H, Catry P (2011) Breaking the routine: individual Cory's shearwaters shift winter destinations between hemispheres and across ocean basins. Proc Biol Sci 278:1786-1793

Egevang C, Stenhouse IJ, Phillips RA, Petersen A, Fox JW, Silk JRD (2010) Tracking of Arctic terns Sterna paradisaea reveals longest animal migration. Proc Natl Acad Sci USA 107:2078-2081

Ekstrom PA (2004) An advance in geolocation by light. Mem Natl Inst Polar Res 58(Spec Issue):210-226

Felicísimo A, Muñoz J, González-Solís J (2008) Ocean surface winds drive dynamics of transoceanic aerial movements. PLoS One 3:e2928

Fridolfsson AK, Ellegren H (1999) A simple and universal method for molecular sexing of non-ratite birds. J Avian Biol 30:116-121

Fry B (1988) Food web structure on Georges Bank from stable $\mathrm{C}, \mathrm{N}$ and $\mathrm{S}$ isotopic compositions. Limnol Oceanogr 33:1182-1190

> Game ET, Grantham HS, Hobday AJ, Pressey RL and others (2009) Pelagic protected areas: the missing dimension in ocean conservation. Trends Ecol Evol 24:360-369

> González-Solís J, Croxall JP, Oro D, Ruiz X (2007) Transequatorial migration and mixing in the wintering areas of a pelagic seabird. Front Ecol Environ 5:297-301

González-Solís J, Felicísimo A, Fox JW, Afanasyev V, Kolbeinsson Y, Muñoz J (2009) Influence of sea surface winds on shearwater migration detours. Mar Ecol Prog Ser 391:221-230

> González-Solís J, Smyrli M, Militão T, Gremillet D, Tveraa T, Phillips RA, Boulinier T (2011) Combining stable isotope analyses and geolocation to reveal kittiwake migration. Mar Ecol Prog Ser 435:251-261

Guilford T, Meade J, Willis J, Phillips RA and others (2009) Migration and stopover in a small pelagic seabird, the Manx shearwater Puffinus puffinus: insights from machine learning. Proc Biol Sci 276:1215-1223

Hedd A, Montevecchi WA, McFarlane Tranquilla L, Burke CM and others (2011) Reducing uncertainty on the Grand Bank: Tracking and vessel surveys indicate mortality risks for common murres in the northwest Atlantic. Anim Conserv 46:30-641

Hill RD (1994) Theory of geolocation by light levels. In: Le Boeuf BJ, Laws RM (eds) Elephant seals: population ecology, behavior, and physiology. University of California Press, Berkeley, CA

Kappes MA, Shaffer SA, Tremblay Y, Foley DG and others (2010) Hawaiian albatrosses track interannual variability of marine habitats in the North Pacific. Prog Oceanogr 86:246-260

Keijl GO (2011) Sooty shearwater Puffinus griseus in the North Atlantic-moult studies using digital cameras.
Mar Ornithol 39:141-142

> Kobayashi DR, Polovina JJ, Parker DM, Kamezaki N and others (2008) Pelagic habitat characterization of loggerhead sea turtles, Caretta caretta, in the North Pacific Ocean (1997-2006): insights from satellite tag tracking and remotely sensed data. J Exp Mar Biol Ecol 356:96-114

> Kopp M, Peter HU, Mustafa O, Lisovski S, Ritz MS, Phillips RA, Hahn S (2011) South polar skuas from a single breeding population overwinter in different oceans though show similar migration patterns. Mar Ecol Prog Ser 435:263-267

> Lyver PO'B, Moller H, Thompson D (1999) Changes in sooty shearwater Puffinus griseus chick production and harvest precede ENSO events. Mar Ecol Prog Ser 188:237-248

- Mackley EK, Phillips RA, Silk JRD, Wakefield ED, Afanasyev V, Fox JW, Furness RW (2010) Free as a bird? Activity patterns of albatrosses during the nonbreeding period. Mar Ecol Prog Ser 406:291-303

Mackley EK, Phillips RA, Silk JRD, Wakefield ED, Afanasyev V, Furness RW (2011) At-sea activity patterns of breeding and nonbreeding white-chinned petrels Procellaria aequinoctialis from South Georgia. Mar Biol 158:429-438

Magalhães MC, Santos RS, Hamer KC (2008) Dual-foraging of Cory's shearwaters in the Azores: feeding locations, behaviour at sea and implications for food provisioning of chicks. Mar Ecol Prog Ser 359:283-293

Marchant S, Higgins PJ (1990) Handbook of Australian, New Zealand and Antarctic birds. Oxford University Press, Melbourne

Mosbech A, Johansen KL, Bech NI, Lyngs P and others (2012) Inter-breeding movements of little auks Alle alle reveal a key post-breeding staging area in the Greenland Sea. Polar Biol 35:305-311

> Nakashima BS (1992) Patterns in coastal migration and stock structure of capelin (Mallotus villosus). Can J Fish Aquat Sci 49:2423-2429

$>$ Opdal AF, Godø OR, Bergstad OA, Fiksen Ø (2008) Distribution, identity, and possible processes sustaining mesoand bathypelagic scattering layers on the northern MidAtlantic Ridge. Deep-Sea Res II 55:45-58

> Paiva VH, Xavier J, Geraldes P, Ramirez I, Garthe S, Ramos JA (2010) Foraging ecology of Cory's shearwaters in different oceanic environments of the North Atlantic. Mar Ecol Prog Ser 410:257-268

> Phillips RA, Silk JRD, Croxall JP, Afanasyev V, Briggs DR (2004) Accuracy of geolocation estimates for flying seabirds. Mar Ecol Prog Ser 266:265-272

Phillips RA, Silk JRD, Croxall JP, Afanasyev V, Bennett VJ (2005) Summer distribution and migration of nonbreeding albatrosses: individual consistencies and implications for conservation. Ecology 86:2386-2396

> Phillips RA, Silk JRD, Croxall JP, Afanasyev V (2006) Yearround distribution of White-chinned petrels from South Georgia: relationships with oceanography and fisheries. Biol Conserv 129:336-347

Polovina JJ, van Howell E, Kobayashi KR, Seki MP (2001) The transition zone chlorophyll front, a dynamic global feature defining migration and forage habitat for marine resources. Prog Oceanogr 49:469-483

> Ronconi RA, Koopman HN, McKinstry CAE, Wong SNP, Westgate AJ (2010) Inter-annual variability in diet of nonbreeding pelagic seabirds Puffinus spp. at migratory staging areas: evidence from stable isotopes and fatty acids. Mar Ecol Prog Ser 419:267-282 
Scott D, Scofield P, Hunter C, Fletcher D (2008) Decline of sooty shearwaters, Puffinus griseus, on the Snares, New Zealand. Pap Proc R Soc Tasman 142:185-196

Shaffer SA, Tremblay Y, Awkerman JA, Henry RW and others (2005) Comparison of light- and SST-based geolocation with satellite telemetry in free-ranging albatrosses. Mar Biol 147:833-843

Shaffer SA, Tremblay Y, Weimerskirch H, Scott D and others (2006) Migratory shearwaters integrate oceanic resources across the Pacific Ocean in an endless summer. Proc Natl Acad Sci USA 103:12799-12802

Shaffer SA, Weimerskirch H, Scott D, Pinaud D and others (2009) Spatiotemporal habitat use by breeding sooty shearwaters Puffinus griseus. Mar Ecol Prog Ser 391: 209-220

Sherwood GD, Rose GA (2005) Stable isotope analysis of some representative fish and invertebrates of the Newfoundland and Labrador continental shelf food web. Estuar Coast Shelf Sci 63:537-549

Sittler B, Aebischer A, Gilg O (2011) Post-breeding migration of 4 long-tailed skuas (Stercorarius longicaudus) from north and east Greenland to West Africa. J Ornithol 152:375-381

Søiland H, Budgell WP, Knutsen Ø (2008) The physical oceanographic conditions along the Mid-Atlantic Ridge north of the Azores in June-July 2004. Deep-Sea Res II $55: 29-44$

Spear LB, Ainley DG (1999) Migration routes of sooty shearwaters in the Pacific Ocean. Condor 101:205-218

Teo SLH, Boustany A, Blackwell S, Walli A, Weng KC, Block BA (2004) Validation of geolocation estimates based on light level and sea surface temperature from electronic tags. Mar Ecol Prog Ser 283:81-98

Uhlmann S, Fletcher D, Moller H (2005) Estimating incidental takes of shearwaters in driftnet fisheries: lessons for the conservation of seabirds. Biol Conserv 123:151-163

Editorial responsibility: Hans Heinrich Janssen, Oldendorf/Luhe, Germany
Veit RR, Pyle P, McGowan JA (1996) Ocean warming and long-term change in pelagic bird abundance within the California Current system. Mar Ecol Prog Ser 139:11-18

Veit RR, McGowan JA, Ainley DG, Wahl TR, Pyle P (1997) Apex marine predator declines ninety percent in association with changing oceanic climate. Glob Change Biol 3:23-28

Wakefield ED, Phillips RA, Matthiopoulos J (2009) Quantifying habitat use and preference of pelagic seabirds using individual movement data: a review. Mar Ecol Prog Ser 391:165-182

Wakefield ED, McFarlane Tranquilla LA, Hedd A, Phillips RA and others (2011) A newly described seabird diversity hotspot in the deep Northwest Atlantic identified using individual movement data. Seabird Group, 11th International Conference, 2-4 September 2011, Plymouth. Abstract. Available at: www.seabirdgroup.org.uk/files/ conference_2011_abstracts.pdf

Walli A, Teo SLH, Boustany A, Farwell CJ, Williams T, Dewar H (2009) Seasonal movements, aggregations and diving behavior of Atlantic bluefin tuna (Thunnus thynnus) revealed with archival tags. PLoS One 4:e6151

Warham J, Wilson GJ, Keeley BR (1982) The annual cycle of the sooty shearwater Puffinus griseus at the Snares Islands, New Zealand. Notornis 29:269-292

Webster MS, Marra PP, Haig SM, Bensch S, Holmes RT (2002) Links between worlds: Unraveling migratory connectivity. Trends Ecol Evol 17:76-83

Woods R, Ingham R, Brown A (2006) Falkland Islands. In: Sanders SM (ed) Important bird areas in the United Kingdom Overseas Territories. Royal Society for the Protection of Birds, Sandy, p 99-162

- Yamamoto T, Takahaski A, Katsumata N, Sato K, Trathan PN (2010) At-sea distribution and behavior of streaked shearwaters (Calonectris leucomelas) during the nonbreeding period. Auk 127:871-881

Submitted: August 23, 2011; Accepted: December 2, 2011 Proofs received from author(s): February 17, 2012 